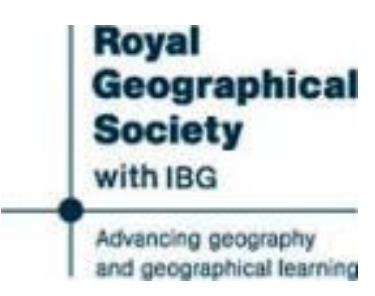

\title{
British East African Plateau Land and Its Economic Conditions
}

Author(s): A. St. Hill Gibbons

Source: The Geographical Journal, Vol. 27, No. 3 (Mar., 1906), pp. 242-257

Published by: The Royal Geographical Society (with the Institute of British Geographers)

Stable URL: http://www.jstor.org/stable/1776423

Accessed: 23-03-2015 20:28 UTC

Your use of the JSTOR archive indicates your acceptance of the Terms \& Conditions of Use, available at http://www.jstor.org/page/info/about/policies/terms.jsp

JSTOR is a not-for-profit service that helps scholars, researchers, and students discover, use, and build upon a wide range of content in a trusted digital archive. We use information technology and tools to increase productivity and facilitate new forms of scholarship. For more information about JSTOR, please contact support@jstor.org.

The Royal Geographical Society (with the Institute of British Geographers) is collaborating with JSTOR to digitize, preserve and extend access to The Geographical Journal. 
leeward sides of both islands there is no fringing reef proper, and the islands are very steep too; but in certain places, sometimes off points, sometimes in bays, the water for 50 to 300 yards from the shore sloped gradually to 12 fathoms, with a bottom of coral sand and mushroomshaped coral patches.

From a distance the island appears flat topped, and the cultivation ground in the centre of the western part, where the forest has been cleared from at least 300 acres, is remarkably level. The same conditions prevail in the forested parts, except that there is a slight rolling uplift along the leeward side, probably not over 4 to 5 feet high and 100 yards wide. On the windward side, very near the cliff-edge, and roughly following its present contour, is a ridge 8 to 15 feet high and 200 yards wide, of apparently tumbled coral masses. The whole top of the island is much weathered, low coral boulders everywhere making walking very difficult. The vegetation is luxuriant, consisting of great forest trees with far-spreading buttress roots, with but little undergrowth in the uncleared portions of the island. In the face of the cliff, whether on the windward or leeward side, there are numerous vertical cracks running from top to bottom, at intervals of, say, 30 to 200 yards. The cracks are narrow, certainly not more than 2 fest wide until 10 to 20 feet above water-level, where the undercutting action of the sea begins ; here they widen out into caves from 3 to 10 feet wide, evidently running many feet back. The only path to the top of the island ends in 25 to 50 feet of what is practically an easy chimney climb. On the weather side of the island a long talus was noted at one spot; this was covered with pandanus and casuarina-elsewhere the latter plant was decidedly uncommon.

(To be continued.)

\section{BRITISH EAST AFRICAN PLATEAU LAND AND ITS ECONOMIC CONDITIONS.*}

\section{By Major A. ST. HILL GIBBONS.}

IT will be remembered that some two years ago an offer of a considerable tract of territory was made by His Majesty's Government to the controllers of the Zionist movement. The principle involved in this offer is quite exceptional, whether viewed from an economic or an administrative standpoint. An autonomous province under a Jewish administration-but subject in certain respects to the control of the Administrator of British East Africa and the Home Government-was to be created within our East African empire. With the political aspect of the offer I have not-nor had I at any time-anything whatever to do, but all must agree that in this respect His Majesty's Government

* Read at the Royal Geographical Society, January 15, 1906. Map, p. 324. 
could have been actuated by none but the highest philanthropic motives. Economically speaking, my view is that a most interesting colonizing problem was involved, for had the scheme been carried through in the spirit in which the offer was made, scientific experiment combined with methodical industrial development should have provided useful objectlessons both to those who settle on the land, and those who control the destinies of our infant colonies.

One of the first conditions imposed in connection with this offer of territory was that a commission approved by His Majesty's Government should proceed to East Africa with instructions to examine the Guas Ngishu plateau - the special territory offered-with a view to reporting on its adaptability to purposes of European agricultural settlement. It was as chief of this commission that $I$ was able to collect the subject matter of this paper. One of my colleagues-Herr Kaiser-was a gentleman of considerable scientific knowledge. As botanist and geologist, he had previously visited Northern and Eastern Africa with the German explorers Schweinfurth and Schoeller. While serving with the latter expedition he had traversed the southern part of this same Guas Ngishu plateau. My second colleague was a gentleman who had never before travelled in Africa.

We landed at Mombasa on January 13, and the following afternoon entrained for Nairobi, having with us the whole of the expeditionary equipment, personal servants, a headman, and a nucleus of ten porters. Feraji, the headman, had crossed Africa with Stanley, and since then had been largely employed on "safari" in East Africa. A single day at Nairobi gave time to arrange matters with the commissioner, the late Sir Donald Stewart, and to augment the caravan to about sixty-the minimum strength I considered adequate for purposes of transport and private service. We reached Nakuro late on the 17th, and on the following day-the fifth since landing at Mombasa-the entire caravan started with loads for the Eldama ravine.

The first day's journey from Nakuro along the Great Rift-valley is dry and shadeless, there being no water until the little Rongai river19 miles away-is reached. This does not flow into the Molo, as shown in the existing maps, but about $6 \frac{1}{2}$ miles north-east of the crossing of the caravan-route all trace of a bed ceases, and the river itself disappears below ground. The water of the Rongai is good, and even at the end of the dry season has a strong flow. An ascent of 1500 feet during a march of 20 miles brought us on the second day to Eldama ravine. The Government station stands in an ideal position on the summit of a steep ascent of some 200 feet, and is all but 7000 feet above sea-level. Though it stands only $3^{\prime} 25^{\prime \prime}$ north of the equator, the Ravine has the reputation of being the most temperate-not to say the coldest-station in the protectorate. There are few healthier spots in Africa or elsewhere. The view is superb. Mount Eldalat, the Mau, the Kamasia 
mountains, and the great rolling forest-clad hills which at 8000 feet form the escarpment of the Guas Ngishu plateau, supply on all sides the background to a heavily wooded undulating country, occasionally relieved by open patches of good natural pasture and the rich red face of the ravine from which the station takes its name. From the Ravine to the south-eastern extremity of the plateau a track through the dense virgin forest-available for foot-passengers only-has been cleared of undergrowth. This leads over steep undulations, each as a rule attaining a higher altitude than the one previously traversed, until finally, after a fair day's march, the forest gives place to a magnificent country of open rolling downs, capable of becoming a great cattle district. Thus on quitting the valley immediately to the west of the Ravine station, the altitude of which is about 6500 feet, the traveller finds himself, in about half an hour, in the Langas valley, at 7410 feet above sea-level; he fullows this stream for over a mile, and then commences a rapid ascent of 750 feet; next he drops 450 , then up and down and up and down, until he stands, at a height of 8650 feet above sea-level, on what is apparently the highest undulation within a comprehensive view. One or two hills at the southern extremity of the Elgeyo escarpment rise a few hundred feet above this, but, excepting Elgon with its 14,200 feet of altitude, and some of the higher peaks of the Chibcharagnani or Chipchangwane mountains-seven good days' march to the north-these south-eastern undulations eclipse in altitude the many considerable hills which, later on in our journey, supplied such excellent landmarks and useful points of observation.

During the first day's journey over these invigorating highlands we crossed the path by which Major (now Sir Ronald) Macdonald traversed the plateau. His name and those of Schoeller, Pringle, and Austin represent the only expeditions which had hitherto visited Guas Ngishu for purposes of geographical research, and their combined work was restricted to a triangle in the southern section of the plateau. Major Austin also passed along the eastern base of Mount Elgon, and the mountain itself, whose towering mass may be seen on a clear day from any part of the plateau from where it is not obscured by intervening obstacles, has been visited at one time or another by protectorate officials and others, notably by Sir Harry Johnston, whose interesting account of his experience created in me a wish that Elgon had been within the scope of our inquiry, or that the time at our disposal had not been so limited as to preclude the possibility of my climbing to the crater.

The first camp on the plateau-8500 feet-was on the fringe of a wide alluvial valley, which will doubtless be ultimately turned to useful agricultural account. Down the centre of it flows the little Kinuyno river, and this, a few miles further, joins the Nesoi-a stronger stream, which a mile beyond the confluence plunges over the Elgeyo 

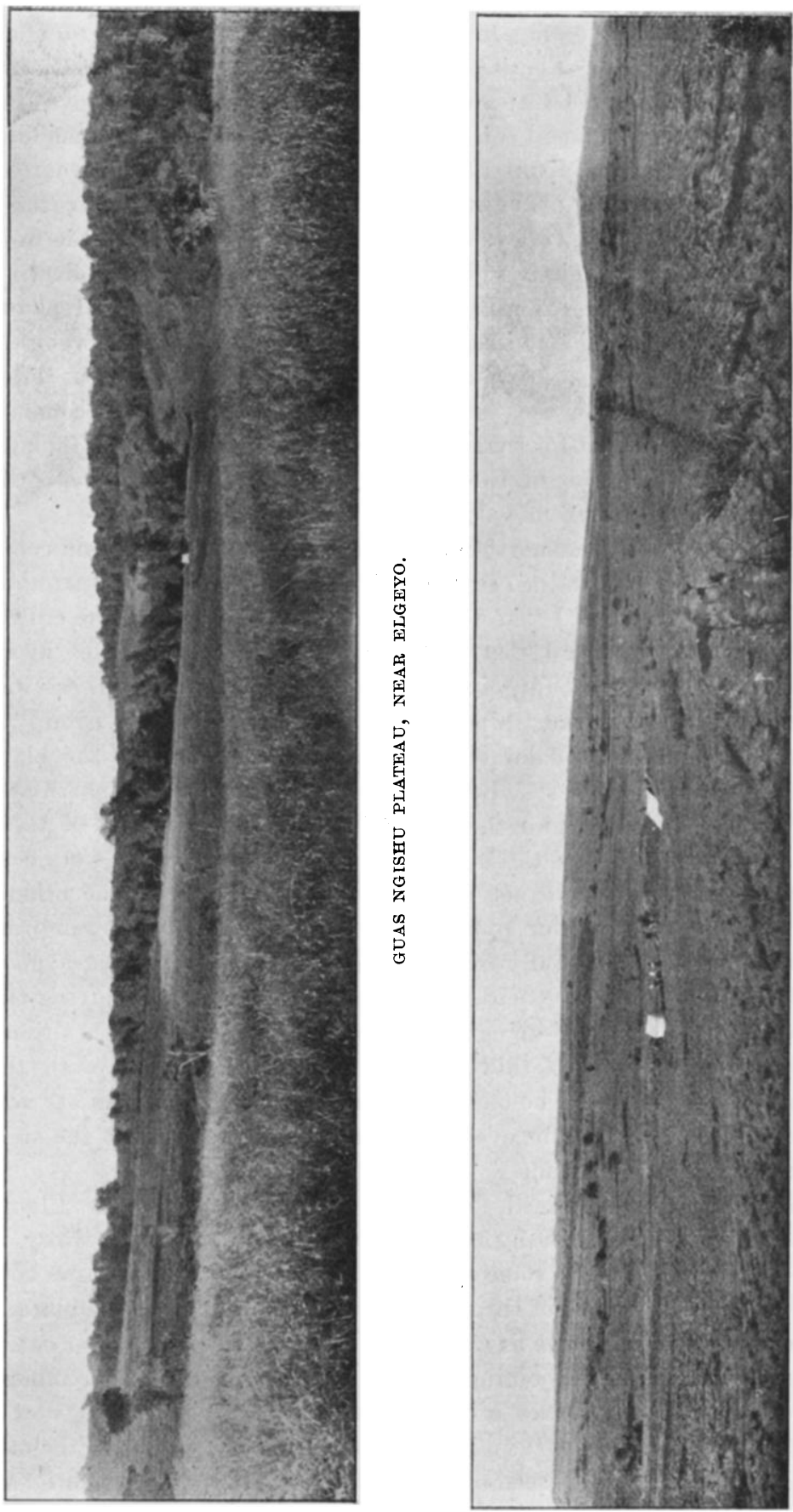

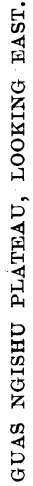


escarpment into the Kerio valley 3000 feet below. Next day we reached what seemed to me to be the ideal spot at which to camp for a few days, while Feraji, the headman, returned to the Ravine for further supplies. Camp was pitched about 30 feet above the springs of a small affluent of the Leosos, known as the Samabula. Beyond the stream, and about 100 yards to the east, were the borders of a considerable patch of primeval forest; to the west alternative grassy undulations and narrow valleys marked a falling away in altitude from 8000 to 7000 feet within half an hour's march. Obviously, the collecting of grasses and a careful examination of the various timbers and plants in the forest would suffice to keep our botanist, Herr Kaiser, thoroughly occupied. For myself, I saw an opportunity, by means of a series or short excursions, not only of studying the material and economic prospects of the district for some miles round, but of laying the foundation of a reliable survey of the plateau on as comprehensive a scale as the few weeks allowed us would permit.

Some 70 miles to the north-north-west a good view of Elgon could almost invariably be obtained in the early morning, and on the summit is a definite point which $I$ take to by the north-castern face of the crater. Slightly to the west and east of north, and 25 and 30 miles away respectively, were Mount Sirgoi and Karuna hill, and beyond these was a prominent peak of the Chipchangwane range, while the group of hills of which Mount Ildalat is the most noticeable breaks the plain 25 miles to the north-west. By a series of observations on north and south stars, I hoped to find the latitudinal positions of each of these points, and also, so far as those lying on my northerly route were concerned, to determine the exact relative distance of each to the others. With this line of bases for purposes of triangulation, I was sanguine that numerous and carefully read compass bearings must give a good result, and, as a commencement, I devoted much of my time during the next fow days to taking bearings on my points from different positions, in order to assure myself that no local variation interfered with the accuracy of the result. The one condition which gave me anxiety was the state of the heavens, for every night since leaving Nakuro the stars had been obscured by clouds.

On one occasion I decided to make a day's excursion to the Elgeyo escarpment, which, as forming the eastern boundary of the territory in question, was a feature of some importance. I took with me three boys and a Masai, who, as one of three professing a knowledge of the plateau, was engaged at the Ravine as a guide. Crossing the stream near camp, we passed through the adjoining belt of forest to the park-like country beyond, where small patches of forest gave relief to the rolling downs characteristic of the country. Two miles of this brought us to the outskirts of 'a forest which seemed to stretch far to right and left. My Masai guide had his work cut out for a couple of hours or more, as, 
with the exception of a half-mile opening along the borders of a marshy stream, every step of the way was contested by an entangled and at times prickly undergrowth. I found ample compensation in the view suddenly encountered on emerging from the forest. So dense are these East African forests up to their very borders, that one frequently does not realize the existence of open country until within half a dozen paces of stepping into it. Such was the case in this instance, and no doubt the sudden contrast in light to some extent enhanced the beauty of the picture in front of me. To the left and left front was apparently illimitable forest; immediately before me a grass bank sloped down to a strong stream, which proved to be the Nesoi; beyond was the face of a second steep undulation, open for the most part, but dotted here and there with small groups of great trees wrapped in vines and under-scrub; while flowing directly towards us from the east was the little Kinuyno, speeding its course in a series of glistening cascades to join the Nesoi on its journey into the great valley beyond the escarpment.

Crossing the Nesoi, I took lunch in a shady spot above a small waterfall, and then proceeded to skirt the forest in an easterly direction until we struck a well-defined native path at the base of a hill whose slopes were covered with forest, but whose summit was clear. This we climbed for some 2000 feet, passing, when near the summit, tbrough thick bamboo forest. From the crest of the hill I could not see as much as $I$ had hoped for, as all distant points to the northwest were obscured by intervening hills. However, I obtained a good view of the south-eastern line of the escarpment, as well as of two important points to the south-west. While descending the hill we encountered two natives, who informed us that they lived in the Kerio valley. Lithe, active-looking fellows of medium height, these people are somewhat extravagantly decorated with beads, wire, and charms. They drape their shoulders with skins, but ignore clothing elsewhere. Their hair is well greased into ringlets with a preparation of fat and red earth, and they carry spear, bow, and arrow. Occasionally during my subsequent journey I met with small hunting parties of these tribesmen, but with the exception of the remote fastnesses of Elgon and the Chipchangwane mountains in the north, I doubt whether a human habitation exists on the plateau at the present time. Occasionally the ruins of unmortared stone walls remind one of the previous existence of a population. That a branch of the Masai race at one time occupied Guas Ngishu is accepted as beyond doubt, and it is also an established fact that their brethren of Naivasha cleared the plateau of settled inhabitants, but so varied are the accounts of this depopulation, both as to time and detail, that the story of the tragedy is largely conjectural. It is, I think, probable that thirty to forty years have elapsed since the plateau became the grand wilderness it is to-day. The people who 
occasionally roam over it for purposes of hunting or depredation are in no way akin to the Masai. Those already described hunt game in the neighbourhood of the Elgeyo escarpment in small parties of six to a dozen. They are harmless, timid, and well disposed. The Nandi and their kindred the Kamasia are more predatory in their habits, and are not above acts of robbery when they see their way to perpetrating them with impunity, and, as can be imagined, the dense forests offer exceptionally good cover to those who desire concealment. On the return journey I avoided the forest by making a southerly détour.

Cloudy nights continued until the second night before striking the Samabula camp, but from that time onwards until our return to Nakuro the heavens smiled upon us, for I seldom missed a night without taking at least three observations for latitude.

I now decided to put into practice the system on which I have always worked in Africa, i.e. allot to each his sphere of action, and leave it to him, untrammelled by others, to carry out his own work in his own way and to his own credit. While I travelled as far north as practicable, and then, gradually trending to the left, described a large circle, my general instructions to Herr Kaiser were, first, to form a base camp as near as water would allow to Mount Sirgoi, a landmark unmistakable from any position in the centre of the plateau; and, second, to visit the lower slopes of Mount Elgon, where interesting botanical and geological results might be expected. Although not possessed of any other surveying instrument than a compass, I trusted that on this plan, since his path would of necessity cross my route twice, his journey would supply a useful addition to the map. Unfortunately, this second condition was not realized, and for this reason I am compelled to accept sole responsibility for the map I place at the disposal of the Society. To my second colleague I gave a free hand.

My instructions to my Masai guide on recommencing the journey were that we would bear north-north-east until we struck the Elgeyo escarpment, which I was anxious to visit. I should state that from the southern point of the escarpment to as far north as the eye could reach from points of vantage near my nortbernmost camp, there extends a belt of primeval forest varying in width up to 8 or 9 miles, and probably wider in the extreme north. Through this a few hunters' paths lead from the plateau to the valley below.

On this occasion my guide started off in the right direction, but later I noticed a distinct tendency to bear westwards. More than once, when paths branched to right and left, and he chose the latter, I protested that it was to Elgeyo, and not to Sirgoi, that we would go, and each time I received a plausible explanation. When towards evening we collided with Herr Kaiser's caravan, and I discovered that we had been led by a circuitous route to the direct road to Sirgoi, things came to a crisis, and the delinquent walked into the forest and 
sulked. I once more bade adieu to my colleague early next day. This time I took the lead, and the guide followed. Half an hour brought us to the edge of the forest, giving a direction slightly north of east. On the average we made progress at the rate of about a mile an hour, being occasionally helped during the afternoon by a network of elephant tracks, most of which were useless to us, as they led to the north and north-west, though a few ran north-east for short distances, and of these we took full advantage. The sun had been down ten minutes when we stepped into the open from a patch of bamboo forest. The aneroid indicated 8600 feet above sea-level. Before us, and apparently covering an area of about 1000 acres, was undulating grassland, occasionally relieved by small clumps or strips of forest trees. A steep slope led to a strong mountain stream of clear cool water flowing westwards. This was apparently the Algarenye, a southern tributary of the Nzoia system. Next morning, on approaching my washing-basin, which always stood outside the tent, filled overnight ready for my morning ablutions, I found the surface to be a sheet of ice about a quarter of an inch thick. The sun had already been up over half an hour when I examined the minimum thermometer. Unfortunately, the spirit had separated, and no indication was left of the minimum night temperature. 'Two other thermometers at the time showed that there were still two degrees of frost, so that probably six or seven degrees could have been registered in the small hours of the morning.

That day I went in search of the escarpment, and in au hour and a half reached it at a spot where the overhanging trees obscured everything but the fact that an almost abrupt precipice lay at my fect. After travelling north-north-west for a further 2 miles, we struck a native path, which led to an open space. When 200 or 300 yards from the escarpment this second time, a great murmuring noise was to be heard ahead. It increased proportionately with our advance, and in a few minutes I fully expected to gaze on a great waterfall plunging over the brink of the escarpment. In a few moments I stood in a position which could not fail to impress the most apathetic temperament with a sense of Nature's grandeur. It is true my waterfall, which would have added lustre to the scene, had proved a myth. I had merely heard a heavy wind striking the face of the precipice below me, and, thus turned upwards, disappearing into space without so much as disturbing a ltaf a few paces from where it dashed impotently against the red-faced cliffe. To the left, a slight curve in the alignment of the escarpment gave the opportunity I looked for to determine for some miles northwards the eastern limit of the territory I had come to examine. In front, I looked straight down without a break into the Kerio valley 3000 feet below me. The scene had the appearance of a great map in relief, with its hills and valleys, its main river-bed and subsidiary watercourses. The Kamasia mountains, which from the 
Rift-valley beyond rank as a considerable mountain range, were dwarfed by the height, from which they were seen 20 miles away. Another 40 miles beyond, the dim blue outline of Laikipia was clearly visible. Next night was spent in the open not far from the previous camp, where clouds had obscured the stars just as I was preparing for a series of observations. On this second night, however, fortune smileả on me, and I was able to fix my position. In this neighbourhood the turf was in places intermingled with clover, and a tasteless raspberry also grows. Perhaps the most striking feature is the beds of white everlasting flowers through which a path had occasionally to be cut. It took a day and a half travelling in a westerly direction to clear the forest on the return journey, though fortunately a small open spacethe only one encountered-supplied a convenient camping-ground, from which I was again able to determine my latitude.

On reaching the open, direction was changed to the nortb, and for a day and a half we passed over downs similar to those already described. Starting at about 8000 feet, with the forest belt on the right and the ground falling away to a vast plain on the left, we gradually dropped to 7400 feet, and camped near Karuna hill, on the edge of the plain itself. Here the ground was dry and the vegetation parched, and it was found necessary to send 2 miles for water. A porous lava was visible in many places, and at best but a thin layer of surface soil covered the rocks.

Four miles north of Karuna we had ascended over downs to an altitude of 7750 feet, and then, in something less than a mile, had dropped nearly 300 feet, and were following the base of a ravine, bounded on the east by a steep heavily wooded slope leading to a continuation of the high ground left behind, and to the west a long hill culminating in five rocky summits, and in reality a spur of the Chipchangwane mountains. Our descent to the lower level had brought us into a broken, hilly district, the existence of which had not been suspected a quarter of an hour earlier. A river, which without doubt is the parent stream of the Nzoia system, skirts the eastern base of this hill, and, rounding the southern extremity, takes a westerly in place of its hitherto southerly course. The next few days disclosed the fact that the depression we had entered extends to the western side of the platean, where it is lost in the gradual decline to its level of the southern plain. It is triangular in shape, and is much broken by stony kopjes and steep hills. A fault running east and west separates it from the plain; the Chipchangwane mountains bound it on the north-east. Following the Nzoia for a few miles, during which progress was very difficult owing to the entanglement of forest undergrowth enshrining every small tributary to be crossed, the absence of native or even game tracks, and the long coarse growth of grass, much of which attained a height of 6 or 7 feet, we finally crossed to the right bank of the 
river (which was about 15 feet wide by 2 feet deep), and pitched camp near the northern end of the hill previously described. Next morning I climbed this hill, while the caravan worked its way round the northern base. The summit commanded an extensive view of the country around. To the north a bold rough country presented itself to my view, where a great group of mountains lay back for many miles, some apparently attaining an altitude of 10,000 to 12,000 feet. One was abrupt and rugged, another of a gentler gradient, a third faced by a great red precipice, and so forth. The general character of the vegetation was grass and scrub, but here and there a hill is covered, or partially covered, with dense virgin forest. It is grand but inhospitable, and probably will remain so long after the neighbouring plains are dotted with homesteads and covered with cattle. To the north-east and east there appeared to be interminable forest, interspersed at rare intervals with small patches of grassland. To pass through this and round the northern base of the mountains as I had hoped to do would require much more time than was allowed me, so I decided to travel along the fringe of the Chipchangwane range in a northwesterly direction. For two days we passed through a mountain valley entirely given over to the beasts of the field. Game was plentiful, and I have never heard so many lions at any one place as I did round my second camp in that valley. The four succeeding days we travelled along high pathless mountainous ground until within 10 miles of the eastern base of Elgon. The satisfactory feature of this part of the journey was that, not only did it take us across the upper waters of the whole of that section of the Nzoia system emerging from the Chipchangwane range, but from the many hills passed over I was able to get a fairly accurate idea of the general flow of the system. I was particularly surprised to find so much water flowing at the very end of the dry season; many streams within quite a short distance of their sources were from 15 to 25 feet wide and 1 to 3 feet deep. Before turning southwards I climbed a hill which commanded a good view of the country as far as Mount Kisimachanga-a north-eastern spur of Elgon connecting that mountain with the Chipchangwane group-as well as of the whole valley to the west and south-west. Immediately between Elgon and where I stood was a belt of undulating grassland some 10 miles in width; to north and south of this a scant acacia savannah extended as far as the eye could reach. On the slopes of Elgon there appeared to be samples of everything already described as existing on the plateau-first savannah, then alternate grass and virgin forest, and above that the rugged boldness characteristic of great mountains. One thing was very noticeable, viz. that the area of plateau-land between the bases Elgon and the Chipchangwane range is only about one-half of that shown in the official map of the district. We now followed a direction slightly west of south, until on the third 
day camp was pitched on the Nzoia river, near a series of rapids about 20 miles from where the river enters the Kavirondo country. The Nzoia was forded at a small rapid where the water was knee-deep, and in places so fast-flowing as to make foothold difficult. The bed of the stream here was 60 feet wide, though in more normal places, where the water is considerably deeper, its average width is little more than half this. We had now sunk to a level of 5650 feet-the lowest altitude we touched on the plateau, though a few miles to both north and south the ground rapidly rises to 6000 feet and over.

The following day we crossed the Kubkong, and camped at the base of a group of granite kopjes, of which Ildalat and Kekupe are the most prominent. The Kubkong is the most important of the Nzoia affuents within the confines of the Guas Ngishu, and drains an area about equal to that section of the Nzoia basin lying above my crossing of the previous day. Yet at the respective crossings the volume of water in the Kubkong was approximately only one-quarter that of the Nzoia; in fact, there appeared to be almost as much water in some of the headstreams of the former river quite close to the Elgeyo escarpment as at this point. The porous nature of the volcanic rock formation, which in the intervening plain lies close to the surface, must account for this depreciation in water-power, for the influence of evaporation in so short a distance with a mean fall of 43 feet in the mile would be inappreciable.

A single day, of which some bours were spent making notes of the surrounding country from the summit of Mount Kekupe, was spent at this camp, and the next evening we camped near Sirgoi. It took two days to discover my colleagues, who were enjoying repose in a hollow 5 miles to the north of Mount Sergoi, and then the return journey commenced.

The game on Guas Ngishu is very plentiful. Hartebeest, topi, zebra, ostrich, water-buck, reedbuck, kob, bushbuck, eland, giraffe, and rhinoceros in the lower country, while numerous elephants and an occasional buffalo confine themselves mainly to the fastnesses of the forest.

In point of altitude, though a very small proportion of Guas Ngishu is under 6000 feet, the basin of the Nzoia where the river quits the territory is about 400 feet below that standard. Extending thence along the eastern base of Elgon northwards there is but an insignificant rise. Passing eastwards from this line, and limited in the north by the Chipchangwane mountains, there is a general rise of 40 feet in the mile until within 15 miles of the Elgeyo escarpment, where the proportionate rise increases to from 100 feet in the south to 70 in the north, culminating in an altitude of about 8500 and 7500 feet respectively. Due east we find the Laikipia plateau falling away in an opposite direction from an altitude at the escarpment of about 7500 feet in the south and 6500 in the north, or about 1000 feet lower than Elgeyo all along the line. It would almost appear, therefore, that the great upheaval 
which created the original plateau centuries before the subsidence of the intervening 50 miles, now occupied by the great Rift-valley, divided it, had its principal point of energy a few miles to the east of the south-eastern extremity of Guas Ngishu-probably where the Kamasia mountains now stand.

A plateau so high above the sea-level, where water flows so rapidly as to deprive the mosquito of his natural breeding conditions, and where there appears to be an almost total absence of that rank river-vegetation he loves so well, should be more than ordinarily healthy. It is true our visit was limited to a few weeks at the end of the dry season, but there is high ground in Africa where the mosquito is not to be found either in the dry or wet season. So too with fly-life generally, although the common fly was troublesome in parts of the Rift-valley, I saw none on the plateau.

Though many readings were taken for maximum and minimum and other temperatures, a single six weeks, commencing towards the end of January, can have but a comparative value. Until within a week of the first shower of the rainy season, when a considerable rise in temperature is to be expected, the maximum was extremely stable, varying only from $71^{\circ}$ to $74^{\circ} \mathrm{Fahr}$., while the mean minimum stood at $40^{\circ}$, though here the range was wider- $37^{\circ} \cdot 5$ to $47^{\circ}$-and on one occasion, already alluded to, sinking to $5^{\circ}$ or $6^{\circ}$ below freezing-point. Here, however, the local conditions were to some extent exceptional, as is shown by the fact that, although Herr Kaiser, who was 9 miles to the southwest, and at an altitude only 500 feet lower, did not read for minimum that night, he registered $3^{\circ}$ Centigrade $=37^{\circ} \cdot 4$ Fahr. at 7 a.m., whereas at the same time my thermometer stood at $30^{\circ} \mathrm{Fahr}$. Comparing these results with monthly averages taken throughout the year on other high ground near the equator, where the monthly variation is not so extreme as in the more northern and southern tropics, we would expect the mean-maximum to vary from $68^{\circ}$ or $70^{\circ}$ in the colder months to approximately $75^{\circ}$ in the hottest montb, and the minimum from $37^{\circ}$ to $45^{\circ}$ respectively, with occasional extremes to $100^{\circ}$ and some half-dozen degrees below freezing-point. Thus there is nothing in the temperature of Guas Ngishu to prejudice its colonization prospects.

Turning to the ultimate material prospects of this district, and, in fact, of East Africa and Uganda as a whole, I admit that it is my firm belief that these protectorates are destined to hold a high position among the future states of our African empire. Not only do I hold them to be "white man's countries," but I believe the higher altitudes will earn a great reputation among the admittedly healthy countries of the world, and that they have a considerable agricultural and pastoral future. I may be too sanguine, but I do not think so. At least, I console myself with the reflection that very little good was ever done in this world without the stimulus of optimism-not to say idealism 
In the interests of all our young African colonies, may we venture to hope that their administration will be carried on in a spirit of optimism. Pessimism and laissez faire spell stagnation; though optimism may not attain its ideal, it will at least leave no stones unturned. The history of the empire is replete with instances in support of this contention, and in Egypt and Rhodesia, Africa itself has within the last fifteen years supplied two remarkable instances of what can be achieved by administrators who take the most liberal view of possibilities. To consider what these countries have been, what they are to-day, and what, in the ordinary sequence of events, they promise to be to-morrow, is but to realize in its full import the distinction between the productive capacity and the economic prospects of a country. The one reminds us of nature pure and simple, the other of nature tempered with industrial and administrative effort.

The territory under discussion comprises some 6000 miles, of which about 400 are covered with a great entangled forest largely composed of podocarpus and juniper. Experts have examined similar forest land lying to the south of the plateau, and have pronounced favourably on a fair proportion of the wood obtainable. Perhaps the tree which most attracts the passing traveller is a giant cedar, which in a long straight trunk towers to a height of about 100 feet. For a rapidly growing local market these forests should afford scope to private enterprise, and at a future period they will, no doubt, supply a profitable export trade, if not to Europe, at least to South Africa, which is extraordinarily deficient in useful timbers. Obviously before this great asset can be exploited on a large scale, not only must branch lines be laid to the bases of operation, but arrangements for very special rates of transit must be made with the controllers of the Uganda railway. Sea-freights, though higher in the East Coast trade than the interests of such an industry would demand, will come down automatically as the volume of trade in general increases, for at sea there is existing competition, which already shows sign of further development as a result of a growing impression that East Africa has a useful future.

Of the rest of the plateau, about one-third is mountainous, and the remainder composed of downs open and undulating or covered with savannah, principally acacia. The soil is chiefly of that red ferruginous clay common to many parts of British East Africa, Uganda, and Central Africa, from the Congo-Zambezi watershed northwards. In the higher altitudes this soil attains a great depth, as may be seen where watercourses have cut a deep bed for themselves. On the whole it grows a good pasture, which ultimately would materially improve with the introduction of cattle to graze it down. For agricultural purposes, this soil is excellent in lowlying land or valleys where it has a chance of ahsorbing moisture; but, generally speaking, where 
this red laterite occurs on Guas Ngishu, the undulations are so steep as to drain rain-water too rapidly over the surface to allow of much penetration. In places where the country is flatter, a yellowish clay is found. This is not so good for agricultural purposes, but grows a fair pasture, though, as a rule, where it occurs the porous lava-bed is so near the surface that towards the close of the dry season the veldt presents a very parched appearance. On the whole, I should say the plateau is unquestionably capable of carrying as much cattle as any other like area in Africa. That grazing stock will thrive, I considered to a great extent proved by the very prime condition of cattle and donkeys at the end of the dry season on a farn provisionally occupied by the three Africander farmers previously mentioned. I was just in time to see these beasts, which were shortly afterwards stolen and driven into the neighbouring forest by a gang of Nandi thieves. Generally speaking, sheep and goats would not do well here, though there are a fow districts, principally in the west and north, where they should thrive. Wild ostriches are found on the Sirgoi flate, so presumably the domestic bird might be kept with advantage. Agriculture, except in small selected districts, is not likely to play more than a very subsidiary part in the future development of Guas Ngishu. Farmers will, no doubt, supply their own needs in cereals and vegetables, but will devote themselves mainly to the raising of stock. Almost any fruit grown in England should do well, though shelter from occasional high winds would be a necessity ; but since eucalyptus, black wattle, and other trees have an abnormal growth-as much as 10 feet in a year-in the highlands of the protectorate, this shelter could be provided, and would in itself return a good profit in a country where its geological structure precludes the probability of the existence of coal deposits. Plants susceptible to the influence of night frosts are out of the question, except, perhups, to the north of Mount Kisimachanga, where the ground slopes down to an altitude of about 4000 feet. I was unable to get so far myself, so cannot give an opinion on that point.

It is probable, then, that the industrial future of Guas Ngishu will in the main be the direct and indirect outcome of the forest-indigenous and planted-and of pasture; rough timber, and live cattle at first, and eventually, no doubt, the carpenter, the cabinetmaker, the tanner, the canner, and other craftsmen will supplement the population. Admittedly the two essential conditions to progress are the existence of markets at which to dispose of produce, and lines of communication to facilitate the carriage of goods to those markets. The so-called absence of markets, so often introduced both by governments and individuals as an excuse for neglecting opportunities, appears to me to be an exaggerated argument which should be banished from the mind of the would-be successful colonizer. By the time a colony has reached even 
the early stage of development, of which East Africa is at present an example, a local market already exists capable of purchasing on good terms all that early industry can produce. My invariable experience has been that, in young colonies, to buy such "luxuries" as vegetables, fruit, eggs, or fresh butter, one has to pay such a price as would cause the English housekeeper to open her eyes, and that such staple articles as wheat have a trebled value. And all this time inferior substitutes are being imported. In the mean time, scores of men roam about the country, trading with natives, shooting, or looking for gold or precious stones, and, in fact, doing everything but attempting to develop the land surface, which is a finer asset than all the undiscovered goldfields in the world, for in agriculture and pasturage there lie the means to establish and support a large, distributed, and increasing settled population. As this grows, so does the local market. As the local market grows, fresh settlers pour in; the development of industry expands; surplus production is no longer a negligible quantity ; the railways, in their own interests, lower their rates and open branch lines as the volume of trade increases; shipping companies compete with one another for a carrying trade now worth catering for ; and thus step by step the conditions now existing in East Africa are substituted for those applicable to the Western States of America and some of our own older and more distant colonies, which can place wheat and other produce on the home market at prices not quite convenient to the home producer.

It is instructive to compare the trade-routes to England from the Western States and up-country East Africa respectively. In the former case, produce is carted to the nearest railway station, sometimes many miles away; it travels some 3000 miles by rail to an eastern port, is shipped, and a further 3000 miles sees it in a British port. East Africa produce will, on an average, travel one-eighth the distance by rail and three times as far by sea. Taking the relative cost throughout the world of land to sea transport, and all other conditions having by the process of competition become equal, the balance lies distinctly in favour of East Africa, and it must be remembered that, in spite of certain drawbacks, the tropics are much more productive than the temperate zones.

But there is another proposition which struck me forcibly when I passed down the Nile from Uganda to Egypt five years ago. That great river is the natural outlet for Uganda and north-western British East Africa, and, with engineering enterprise and expense quite trivial as compared with what has already been done in Egypt, can be made navigable from Lake Albert to Upper Egypt. Indirectly and directly, Sir William Garstin's great scheme for the canalization of the Nile from Bor to Fashoda should do much for these protectorates. Firstly, it will save the millions of gallons of water continually evaporating in 
the sudd expanse, and thus swell the river to such an extent as will probably give to the lower Nile an increased volume even after the demands of irrigation have been met. This may suggest to the Egyptian Government the economic advantages of a navigable waterway through the cataract district to the Mediterranean. Secondly, this great work will so vastly widen the area of cultivation as to reestablish Egypt as one of the world's great granaries. With the establishment of this new era, Mediterranean sea-freights will become proportionate to those on the Atlantic, and Uganda will share the advantage with Upper Egypt-for a journey a few days longer in a Nile barge will not materially add to expense in transit.

Before the reading of the paper, the President said: The Fellows will, I am sure, welcome the presence on this platform of Major Gibbons, who has given us more than one valuable address. The last occasion, if my memory serves me right, was some five years ago, when Major Gibbons placed before us the geographical results of his extensive explorations in Barotseland. You may remember that he received high encomiums both from our recent President, Sir Clements Markham, and from other Fellows of the Society, in respect of the thoroughness of his work. It was, therefore, no surprise to us to learn two or three years later that he had been selected as the most suitable available person, unconnected with and independent of the administration of East Africa, to go to the Guas Ngishu plateau and report upon its prospects as an outlet for the Zionist movement, or perhaps I should now say, the Jewish Territorial Organization. The general principles underlying that movement probably command the sympathies of most thinking persons in our liberty-loving land, although, naturally, there is considerable division amongst us, just as there is amongst the Zionists themselves, as to the particular direction which their energy should take. I have referred to this subject because it is a question of the moment, so that it lends a special and immediate interest to the paper of the evening, apart from the general interest which the Royal Geographical Society must always take in the development of an unsettled region, and especially if that region falls within the circle of the British Empire. And if any one should feel inclined to suggest that the particular subject to which I have referred does not come strictly within the purview of geography, I would plead that geographical science, which has borrowed so much from, and has lent so much to, various other departments of human knowledge, cannot afford to dissociate itself from sociological or ethnological questions, or indeed from any questions which relate, even remotely, to the reactions between mankind and the elements and forces of its environment. I now invite Major Gibbons to read his paper.

After the paper, the President said: We are so fortunate as to have with us to-night perhaps the highest authority on general questions connected with East Africa. I refer to Sir Charles Eliot. I know that he has pledged himself to deliver an address elsewhere on this subject to-morrow night, and it would not be fair to ask him to encroach too much on what he is then going to say; but I have no doubt he will be able to give us a few interesting observations out of the wealth of his knowledge of the country in question.

Sir ChaRles Eliot : I have listened with great pleasure to the very interesting paper which Major Gibbons has read. I know something of the part of Africa with which he has dealt. I have made two journeys in it myself, one

No. III.-March, 1906.] 


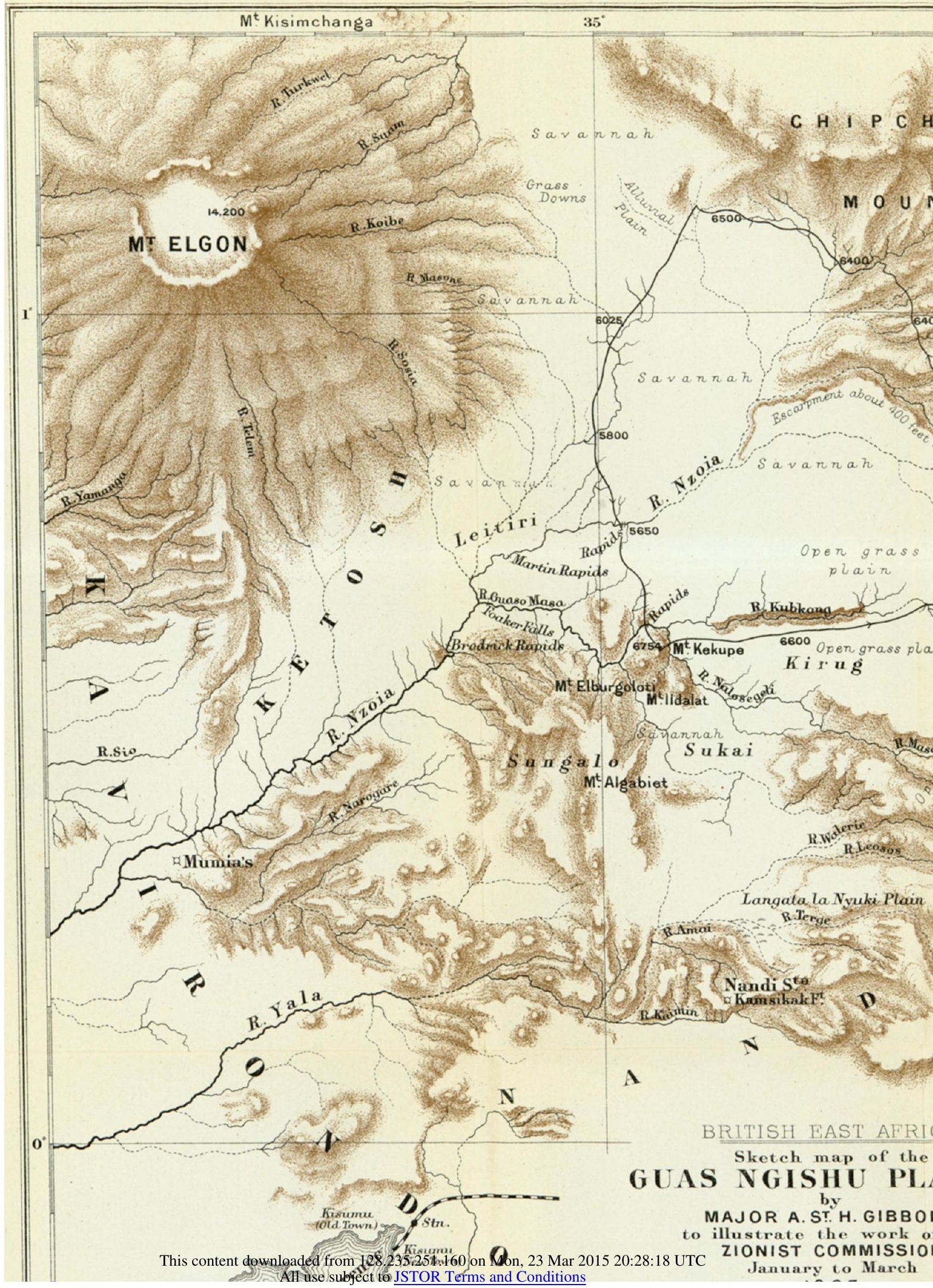


GUAS NGISHU PLATEAU.

Gibbons.

THE GEOGRAPHICAL JOURNAL, 1906

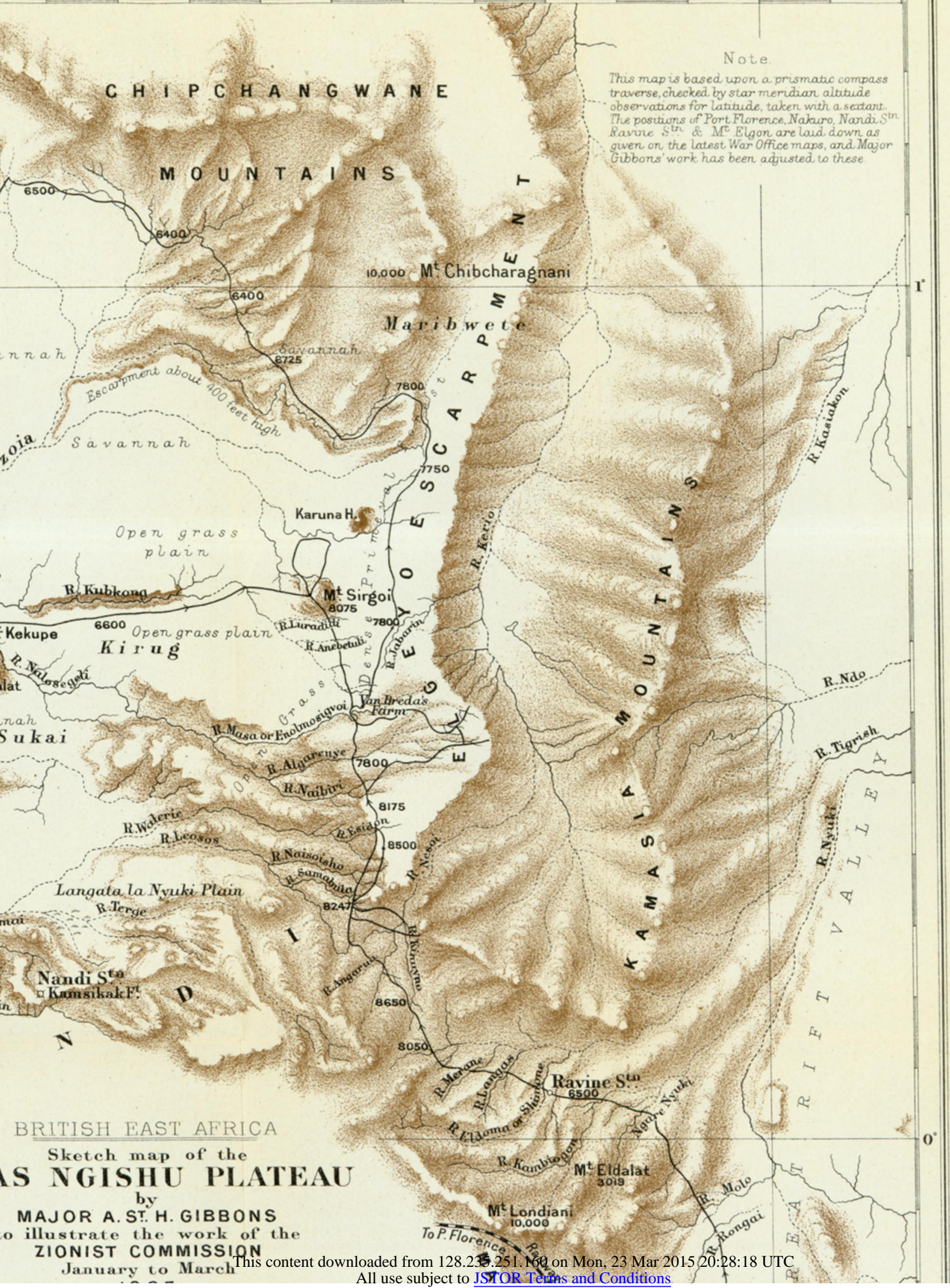




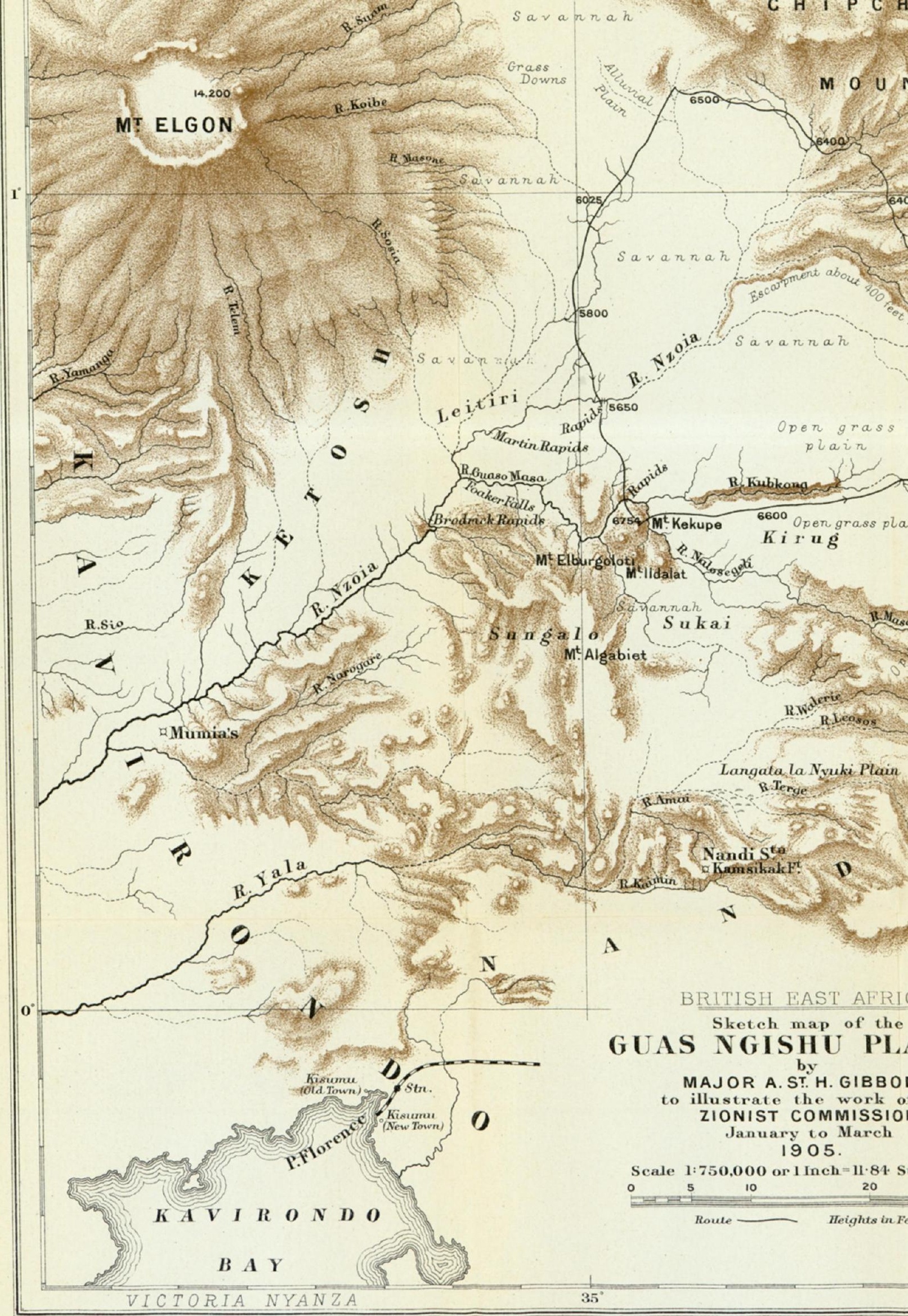

Published by the Royal Geographical sor 
